\title{
二次元ラム加速器始動時の数値計算*1
}

\section{Numerical Simulation of the Starting Process in Two-Dimensional Ram Accelerator}

\author{
張 慈 亨*2 滝 史 郎*2 \\ Ciheng ZHANG, Shiro TAKI \\ 張 新 宇*2 \\ and Xinyu CHANG
}

Key Words : Shock Waves, Ram Accelerator, Detonation, Combustion, Numerical Simulations

\begin{abstract}
Direct numerical simulations are tried using finite difference methods to investigate the starting processes of the ram accelerator in Hiroshima University, the ram acceleration tube of which has a rectangular bore for easy observation. A projectile and an igniter fly at speed below C-J velocity from an evacuated chamber into a ram acceleration tube, where hydrogen-oxygennitrogen gas mixtures are filled as combustible gases. When the acceleration tube is filled by carbon dioxide as a non-reactive gas for the first test, the results of the numerical solutions give a good agreement with the experimental results. When combustible gas mixtures are filled in the acceleration tube, we could not get a solution without detonation or quenching. This kind of difficulty to start is also found in the experiments. The numerical results show how the igniter works in the starting process, those help our experiments.
\end{abstract}

$$
\text { 主な 記 号 }
$$

$N:$ 化学種の総数

$D_{i j}:$ 化学種 $i$ と $j$ の間の二体拡散係数

$e:$ 比全エネルギー

$h$ : 比エンタルピー

$h_{i}:$ 化学種 $i$ の比エンタルピー

$J_{i}$ : 化学種 $i$ の拡散フラックス

$p$ :压力

$\boldsymbol{q}:$ 熱フラックス

$T:$ 温度

$u, v: x$-及び $y$-方向の流速

$V_{i}$ : 化学種 $i$ の㹡散速度

$w_{i}$ : 化学種 $i$ の質量生成速度

$X_{i}$ : 化学種 $i$ のモル分率

*1 平成 9 年 7 月 14 日原稿受理

*2 広島大学工学部第一類

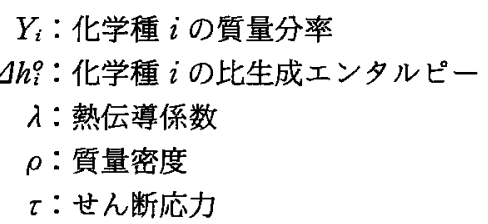

\section{1. 序論。}

ラム加速器はHertzberg, Bruckner ら"米国 Washington 大学のグループによって 1980 年代に研 究が始められ，今日いくつかの国で実験と数值計算に よる研究が進められている2-4). 飛玤体それ自身に推 進装置を持たなくても，その外部の混合気の燃焼によ ってかなりの高速にまで加速することができるので， 宇宙機など飛翔体を経済的に飛行させる装置となる可 能性がある．またスクラムジェットに扔けるディフュ ーザーを模擬した簡易な実験装置としての役割も果た しうると考えられ，高速流中での燃焼実験装置として の可能性がある.

この装置は开翔体を最初に発射装置である程度の速 度にして, 可燃性混合気で満たされたラム加速管の中 に打ち込み，混合気の燃焼のエネルギーで飛翔体を加 速するものである．作動させる上で最も難しいところ は，作動を開始させるときである．すなわち，可燃性 混合気に点火し，飛翔体後方で安定に燃焼を保持でき るようにする必要がある. 㚣翔体の速度が混合気の Chapman-Jouguet デトネーション速度以上であれ ば、飛翔体によって作られる衝撃波による加熱で比較 的容易に燃焼を保持できると考えられるが，目的から してもそのような大きな初速度は実用的ではない.C. J 速度以下でラム加速させるには, 燃焼の発熱によっ て流れをチョーキングさせ，その圧力で強い垂直衝撃 波を飛㓞体と管壁の間につくりその後方で然焼を保持 するチョーキング・モードと呼ばれる状態にする必要 
があると考えられている。

我々のグループはラム加速管の断面が矩形をした小 型ラム加速器を開発中である ${ }^{5,6)}$. 従来のラム加速器 はすべて円形断面であるが，基礎実験用には観測，特 に可視化の容易さが重要であると考えて矩形断面を採 用した、これまでのラム加速器と同様, 我々の装置に おいても試験段階で始動の困難さは大きな問題となっ ている．特に我々の装置はラム加速管内の圧力が低 く，点火方法も異なっており，その非定常現象を解明 して解決法を探ることを目的に数值シミュレーション を開始した7). 本論文は点火用物体を含めた始動時の 数值シミュレーションの第 1 報である.

\section{2. 計 算モテル}

2.1 装置 我々が開発中のラム加速器については すでに文献 5) などで述べられているが，第 1 図にそ の概要を示す．駆動用に気体デトネーションを用いた 二段軽ガス銃で飛翔体を発射する。駆動用ガスを排気 する排気室を経て，ラム加速管へ飛翔体を过く，最終 的には飛翔体はキャッチャ管て止められる.ラム加速 管は断面が矩形で高さ $20 \mathrm{~mm}$, 幅 $15 \mathrm{~mm}$ で側面中央
部に細いレールがあり姿势・位置が保持される．矩形 断面形状に対して 2 次元に近似できるとして計算す る. 本数值シミュレーションは我々の害験の排気室か らラム加速管へ飛㓞体が入るところからスタートす る. $2 つ の$ 部屋の間には隔膜があるが, 計算では飛㓞 体頭部によって瞬時に破膜され，無くなるものと仮定 する。

飛翔体は先頭のくさび角 $20^{\circ}$ て上下対称になってお り，肩の部分の高さは $12 \mathrm{~mm}$, 全長 $53 \mathrm{~mm}$ のプラス チック製である．飛翔体に続いてその直後に直方体を した点火用物体がラム管に突入する. 点火用物体は長 さ $7 \mathrm{~mm}$ 程度で高さは $12 \mathrm{~mm}$ まで各種ある。いずれ も上下対称で計算では現象も上下対称と仮定して半空 間を解くことにする. 飛吽体の質量は幅 $1 \mathrm{~mm}$ あたり $0.3 \mathrm{~g}$ で, 点火用物体は高さ $12 \mathrm{~mm}$ のもので幅 $1 \mathrm{~mm}$ あたり $0.067 \mathrm{~g}$ とした。

2.2 燃焼反応 本計算では反応機構がよく分かっ ていて比較的簡単な連銷反応からなる水素酸素系を用 いる. 実験では種々の理由によりメタン酸素系を用い ている. 両者に燃焼特性の違いはあるが, ラム加速器 の特性を調べるという目的に対してあまり問題はな

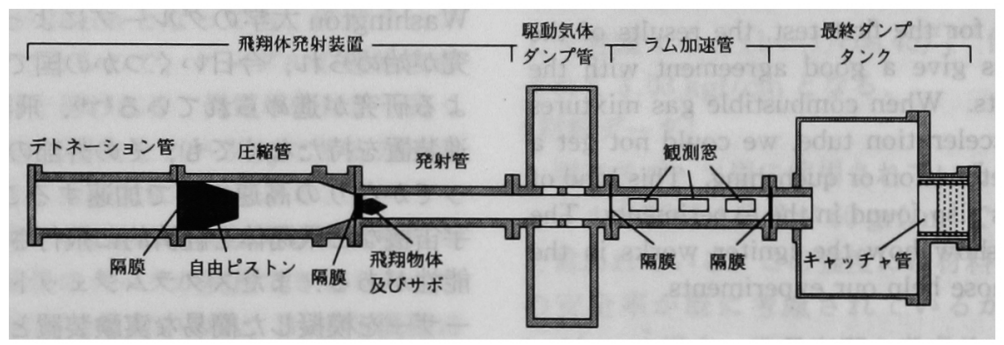

第 1 図 広岛大学ラム加速器の概念図

第 1 表 水素酸素系の美反応と速度定数（倉谷"などより） Forward rate ; $B_{j}=k_{j} T^{n \prime} \exp \left(-E_{j} / T\right)$

\begin{tabular}{cccrr}
\hline$j$ & Elementary reaction & $k_{j}(\mathrm{~m}, \mathrm{~s}, \mathrm{kmol})$ & $E_{j}(\mathrm{~K})$ & $n_{j}$ \\
\hline 1 & $\mathrm{H}_{2}+\mathrm{O}_{2} \rightleftharpoons 2 \mathrm{OH}$ & $1.7 \times 10^{10}$ & 24,200 & 0 \\
2 & $\mathrm{H}+\mathrm{O}_{2} \rightleftharpoons \mathrm{OH}+\mathrm{O}$ & $2.2 \times 10^{11}$ & 8,455 & 0 \\
3 & $\mathrm{O}+\mathrm{H}_{2}=\mathrm{OH}+\mathrm{H}$ & $1.8 \times 10^{7}$ & 4,480 & 1 \\
$4^{\mathrm{B}}$ & $\mathrm{H}+\mathrm{O}_{2}+\mathrm{M} \rightleftharpoons \mathrm{HO}_{2}+\mathrm{M}$ & $1.59 \times 10^{9}$ & -500 & 0 \\
5 & $\mathrm{H}+\mathrm{HO}_{2} \rightleftharpoons 2 \mathrm{OH}$ & $2.5 \times 10^{11}$ & 950 & 0 \\
6 & $\mathrm{OH}+\mathrm{H}_{2} \rightleftharpoons \mathrm{H}+\mathrm{H}_{2} \mathrm{O}$ & $2.2 \times 10^{10}$ & 2.590 & 0 \\
7 & $\mathrm{OH}+\mathrm{OH} \rightleftharpoons \mathrm{O}+\mathrm{H}_{2} \mathrm{O}$ & $5.5 \times 10^{10}$ & 3.520 & 0 \\
$8^{\mathrm{b}}$ & $\mathrm{H}+\mathrm{OH}+\mathrm{M} \rightleftharpoons \mathrm{H}_{2} \mathrm{O}+\mathrm{M}$ & $1.6 \times 10^{16}$ & 0 & -2 \\
9 & $\mathrm{H}_{2}+\mathrm{HO} \mathrm{O}_{2} \rightleftharpoons \mathrm{OH}+\mathrm{H}_{2} \mathrm{O}$ & $2.0 \times 10^{8}$ & 12,000 & 0 \\
10 & $\mathrm{OH}+\mathrm{HO}_{2} \rightleftharpoons \mathrm{H}_{2} \mathrm{O}+\mathrm{O}_{2}$ & $1.6 \times 10^{10}$ & 0 & 0 \\
11 & $\mathrm{O}+\mathrm{HO}_{2} \rightleftharpoons \mathrm{OH}+\mathrm{O}_{2}$ & $4.8 \times 10^{10}$ & 500 & 0 \\
12 & $\mathrm{H}+\mathrm{H}^{10}=\mathrm{H}_{2}+\mathrm{M}$ & $1.0 \times 10^{11}$ & 0 & -1 \\
$13^{\mathrm{c}}$ & $\mathrm{O}+\mathrm{O}+\mathrm{M}=\mathrm{O}_{2}+\mathrm{M}$ & $1.9 \times 10^{7}$ & -900 & 0 \\
\hline
\end{tabular}

Third body factor : " 18 for $\mathrm{H}_{2} \mathrm{O},{ }^{b} 4$ for $\mathrm{H}_{2} \mathrm{O},{ }^{\mathrm{c}} 3$ for $\mathrm{O}$. 
い. 水素酸素系の素反応の連鎖としては，計算時間の 短縮のため過酸化水素は無視して，第 1 表に示すよう な 13 往復の素反応を考えることにする．希釈気体と して窒素を用いるが, 非活性とみなし, 化学種として は $\mathrm{O}_{2}, \mathrm{H}_{2}, \mathrm{O}, \mathrm{H}, \mathrm{OH}, \mathrm{HO}_{2}, \mathrm{H}_{2} \mathrm{O}$ 及び $\mathrm{N}_{2}$ の 8 種 を考える。

2.3 状態方程式 本数值シミュレーションではあ まり高い圧力まで扱わないので, 各化学種は熱的に完 全気体であるとみなすことができる．しかし温度範囲 は広いので熱量的には完全とみなすことはできず，各 化学種の比エンタルピーを次のように温度 $T$ の多項 式に近似する。

$$
h_{i}=\sum_{k=1}^{6} h_{i}^{k} T^{k-1} \quad(i=1, \cdots, N)
$$

混合気の比全エネルギー $e$ は

$$
e=h-\frac{p}{\rho}+\frac{1}{2}\left(u^{2}+v^{2}\right), \quad h=\sum_{i=1}^{N} h_{i} Y_{i}
$$

である. 各化学種の Gibbsの自由エネルギーもこれ ら温度多項式の係数を用いて温度の多項式で表わすこ とができ，それを用いて得られる化学平衡定数より素 反応の逆反応の速度を求められる。

2.4 輸送フラックス 火炎においては拡散と熱伝 導がその伝播に支配的な影響を与える。

拡散フラックス:化学種 $i$ の拡散フラックス $J_{i}$ は 圧力拡散・熱拡散を無視して, 次の拡散方程式より求 められる。

$$
\begin{aligned}
& \frac{\nabla X_{i}}{X_{i}}+\sum_{j=1}^{N} \frac{X_{j}}{D_{i j}}\left(\boldsymbol{V}_{i}-\boldsymbol{V}_{j}\right)=0, \\
& \boldsymbol{J}_{i}=\rho Y_{i} \boldsymbol{V}_{i} \quad(i=1, \cdots, N)
\end{aligned}
$$

熱フラックス：簡単のために輻射の影響は無視でき るものとする．また計算では管壁や飛翔体表面での熱 伝達は無視できるとして，断熱壁を仮定する．熱フラ ックス $\boldsymbol{q}$ は熱伝導と拡散によって生じ，

$$
\boldsymbol{q}=-\lambda \nabla T+\sum_{i=1}^{N} h_{i} \boldsymbol{J}_{i}
$$

粘性：ラム加速器の始動の可能性を探る本計算て は，境界層が高速の流れ場に大きな影響を与えないと みなして，飛翔体表面及び管壁における粘性を無視し て計算時間とメモリーの節約を図る。

2.5 保存方程式 流机場を支配する方程式は質 量・運動量・エネルギー及び各化学種の保存方程式か ら基本的に成り立っている．2次元デカルト座標を用 いて保存系で表わせば以下のようになる。

$$
\frac{\partial}{\partial t}\left[\begin{array}{c}
\rho \\
\rho u \\
\rho v \\
\rho e \\
\rho Y_{i}
\end{array}\right]+\frac{\partial}{\partial x}\left[\begin{array}{c}
\rho u \\
\rho u^{2}+p+\tau_{x x} \\
\rho u v+\tau_{y x} \\
u(\rho e+p)+u \tau_{x x}+v \tau_{y x}+q_{x} \\
\rho Y_{i}\left(u+V_{i x}\right)
\end{array}\right]
$$

$$
+\frac{\partial}{\partial y}\left[\begin{array}{c}
\rho v \\
\rho v u+\tau_{x y} \\
\rho v^{2}+p+\tau_{y y} \\
v(\rho e+p)+v \tau_{y y}+u \tau_{x y}+q_{y} \\
\rho Y_{i}\left(v+V_{i y}\right)
\end{array}\right]=\left[\begin{array}{c}
0 \\
0 \\
0 \\
0 \\
w_{i}
\end{array}\right]
$$

\section{3. 計 算 法}

計算には基本的に陽的差分法を用いるが，化学反応 の積分や熱伝導には陰的方法を用いるなどいくつかの 方法を組み合わせて行う。飛翔体や点火用物体には抗 力あるいは推力が働き速度や両者の相対的位置が変化 するので，適切な差分格子と境界条件を与える必要が ある．また火炎を正しく解くにはかなりの空間分解能 が要求されるので, 細かい差分格子を用いる必要があ る。

3.1 解適合多重レベル差分格子細分化法 解こう とする空間内でも場所によって必要な分解能が大きく 異なるため, 差分格子を局所的に細分化する方法はい くつか考えられている．特に火炎は高い空間分解能を 必要とするた゚けでなく，その位置や形状が大きく変化 する．このような問題に対応できるように筆者らが開 発した解適合多重レベル差分格子生成法9) は，各レべ ル毎に格子間隔が $1 / 3$ ずつになり，レベルを 5 段階に とれば最も粗い格子を $1 \mathrm{~mm}$ としたとき最も細かい格 子は約 $12 \mu \mathrm{m}$ であり, 常圧の火炎の厚さ $100 \mu \mathrm{m}$ 程 度を解くことが十分可能になる．高圧になるデトネー ションが生じた場合は衝擊波加熱による燃焼のため， 熱伝導や搪散の影響は無視してむしろ少し粗い約 37 または $111 \mu \mathrm{m}$ の格子を用いた. 各レベルの格子の生 成あるいは抹消の基準は各レベル毎にいくつかの条件 で設定できるようになっている．水素酸素火炎につい ては $\mathrm{OH}$ または $\mathrm{H}$ ラジカルの質量分率の隣接する格 子間の比，あるいは温度勾配を基準に捕獲する．衝撃 波は火炎より粗い格子レペルで捕獲し，圧力勾配を基 準にする。

格子の形は一般曲線座標でもこの格子細分化法を適 用できるが，本計算では差分計算に優れた性質を持つ 正方形を用いた.

3.2 時間分割法 支配方程式は種々の性質を持っ た偏微分方程式であり，解こうとする問題は局所的に 支配的な特性が変化する複雑な場であるため，それぞ れ性質毎に適した計算法で解くことにする。非定常問 題では時間精度も2 次以上を保つのがよいとされてお り,ここでは特性毎の項に分けて時間積分する時間分 割法を採用することにする. 反応による生成項は一段 
階陰的方法で時間 2 次精度である Lomax-Baily の方 法 $^{10)}$ によって積分する。輸送項はそれぞれ別個に2 次精度以上の陰的また㹥陽的方法を用いて積分する。 ただしいずれも現象に影響をほとんど与えないところ では無視される。 また双曲型の項は 2 次精度陽的 MacCormack 法を用いるが，粗くてよいところでは 1 次精度の van Leer の方法 ${ }^{11}$ を使う。このような区 別は多重レベルの差分格子を用いているため極めて容 易にでき，この点でも計算時間の短縮に多重レベル差 分格子細分化法は有効である。

3.3 移動境界法 飛翔体と点火用物体の 2 つの物 体周りの反応流れ場を解く. 適切な境界条件を与えや すくするためには差分格子を物体と共に移動させるの が良いが，2つの物体にはそれぞれ独立に抗力あるい は推力が働き, 速度及び相対位置が変化する。 そこで 本計算では飛翔体に乗った差分格子系と点火用物体に

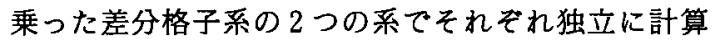
し，2つの系を接続させる．接続にはそれぞれ系の計 算領域の外側に境界値を与えるために設けた格子点位 置の状態量を，別の系の該当する位置の状態として内 挿して求める.この際, 気体の運動量及び運動エネル ギーが 2 つの系の間で異なることに注意する必要があ る. 両者は $x$ 方向のみに運動するので, その速度成 分のみを考える. 飛翔体に乗った系（添え字 p）の移 動速度を $U_{\mathrm{p}}$, 点火用物体に乗った系（添え字 s）の 移動速度を $U_{\mathrm{s}}$ とすると，2つの系における流速 $u_{\mathrm{p}}$ と $u_{\mathrm{s}}$ との関係は次式のようになる。

$$
U_{\mathrm{p}}+u_{\mathrm{p}}=U_{\mathrm{s}}+u_{\mathrm{s}}
$$

したがって比全エネルギーeは運動エネルギーの差 だけ異なって，次式の関係になる。

$$
e_{\mathrm{p}}-\frac{1}{2} \rho u_{\mathrm{p}}{ }^{2}=e_{\mathrm{s}}-\frac{1}{2} \rho u_{\mathrm{s}}^{2}
$$

2 つの物体の運動はそれぞれの表面に働く圧力分布か ら物体に衝く力を求めて解く.

点火用物体より後流ではチョーキングする要因もな く，超音速流であるため必ずしも解く必要はない，点 火物体と管壁との間の後方では気体が音速以上の速さ で流出しているので，擾乱が前方の計算領域に伝わら ない位置で気体が零勾配で流出する境界条件で近似し た.また点火物体に働く力を算出する際には, 物体後 表面の圧力は物体前面に比べ，無視できるほど小さい ので, 圧力を零と近似した。

\section{4. 計 算 結 果}

4.1 非反応性気体中 実験の進め方と同様に、最 初のテストとしてのコールド・ショットすなわち非反 応性気体中へ我翔体と点火用物体を打ち込む数值シミ ュレーションから始める。これは衝撃波が飛翔体前方 につくられないことを確認するテストである．計算結 果を第 2 図に等圧力線図の時間経過で示し，第 3 図に 計算結果と比較して実験結果を示す。ラム加速管内は 初期圧力 $0.30 \mathrm{MPa}$, 初期温度 $288.15 \mathrm{~K}$ の二酸化宸

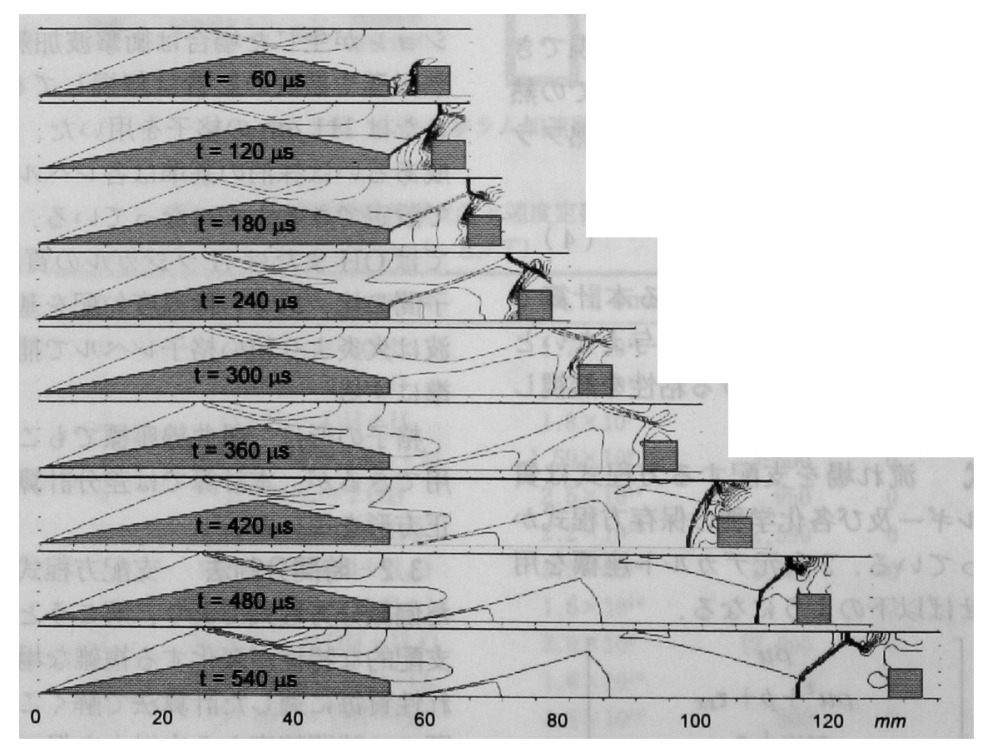

第 2 図 非反応性気体の場合の計算結果一等圧力線図の時間変化 ラム加速管内の気体は二酸化炭菜て，初期圧 $0.30 \mathrm{MPa}$ ，初期温度 $288 \mathrm{~K}$. 飛翔体と点火用物体の初速度は $1100 \mathrm{~m} / \mathrm{s}(M=4.1)$. 
素で充たされ，そこへ飛㓞体と点火用物体が初速度 $1100 \mathrm{~m} / \mathrm{s}(M=4.1) て ゙$ 真空（ここでは $0.1 \mathrm{~Pa})$ の排 気室の管より突入する，この場合は，飛㓞体は質量 $6.0 \mathrm{~g}$ で点火用物体は $0.8 \mathrm{~g}$ である。計算では飛玤体 先頭が加速管入り口にきたときを時刻零とし，その瞬 間に隔膜がなくなるとしている．破膜されるとラム加 速管内の気体は排気室へ噴出しはじめ，飛翔体はその 中を進み，一方，点火用物体の前には離脱衝擊波がつ くられる. 飛翔体先頭部から斜め衝撃波が生じ反射波 が後方につくられる. 点火用物体のつくる衝撃波背後 の圧力によって点火用物体は急速に速度を落とし, 飛 翔体から離れていく，飛翔体先頭のつくる斜め衝撃波 が繰り返し反射し，点火用物体がつくる衝撃波と干涉 してやや複雑な衝撃波が見られる。

このようなコールド・ショットの我々のグループの 実験結果は文献 6)で報告されているが，比較のため に数値計算とほほ同じ条件の実験結果を第 3 図(a)に 示す。第 3 図(a)はラム加速管入り口からそれぞれ $100 ， 470 ， 1270 ， 1970 \mathrm{~mm}$ の位置に設置された $4 つ$ の測定点における圧力波形（PT 1 4）と磁気センサ 一信号波形（MD 1 4) である. 磁気センサーは飛翔 体の通過した時刻を示し，各測定点で圧力波の先頭と
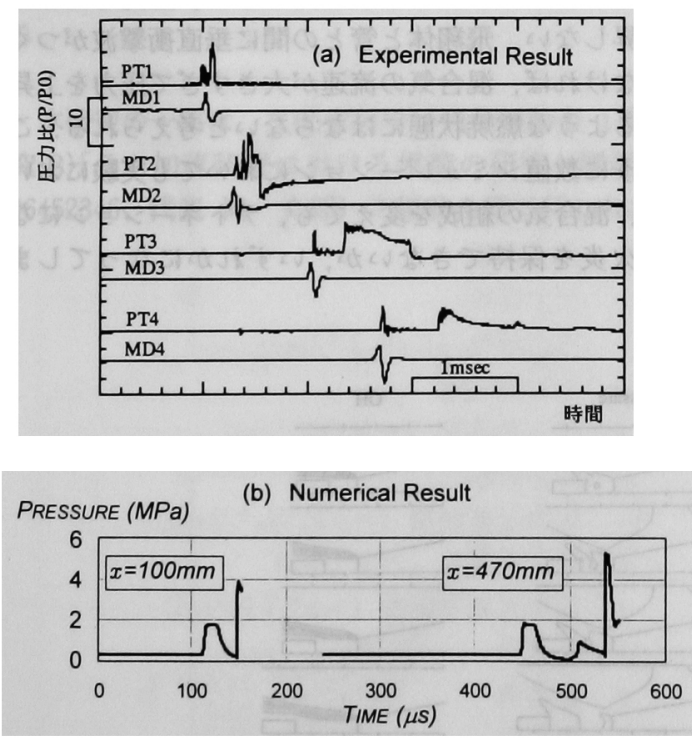

第 3 図非反応性気体を用いた実験結果 (a)と計算結果の 圧力波形(b)

ラム加速管は圧力 $0.30 \mathrm{MPa}$ の二酸化宸素. 飛 翔体と点火用物体の初速度 $1100 \mathrm{~m} / \mathrm{s}(M=4.1)$. (a)の実験結果は 4 つの測定点における圧力七ン サー（PT）及び磁気センサー（MD）からの出 力．測定点はラム加速管入り口からそれぞれ 100 $\mathrm{mm}, 470 \mathrm{~mm}, 1270 \mathrm{~mm}, 1970 \mathrm{~mm}$ である.

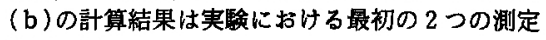
位置に対応する。
ほほ一致することがわかる。第 3 図(b) は第 2 図に示 した数值計算結果から得られた測定点 $1(x=100 \mathrm{~mm})$ と $2(x=470 \mathrm{~mm})$ における圧力波形である. 先頭衝 撃波による圧力上昇から離脱衝撃波による圧力上昇ま での時間は， $x=100 \mathrm{~mm}$ にいて, 計算結果は 33 $\mu \mathrm{S}$ で実験結果は $58 \mu \mathrm{s}$ であり， $x=470 \mathrm{~mm}$ で計算は $87 \mu \mathrm{s}$, 実験は $110 \mu \mathrm{s}$ である. 計算と実験の差は 2 点 であまり違いはなく，飛翔体と点火用物体との間隔が ラム加速管突入時に両者で異なっているためと考えら れる。また離脱衝撃波の 2 点を通過する時間間隔は計 算では $390 \mu \mathrm{s}$, 実験では $375 \mu$ 索であり，計算では物 体とレールの間の摩擦などを無視していることを考え ると,よく一致しているといえる。

4.2 可燃性混合気中 次に可燃性混合気をラム加 速管内に充媜した場合の数值シミュレーションを行 う。その結果の一例を第 4 図に等温度線図と等圧力線 図の時間経過として示す．混合気の組成は窒素希釈し た量論混合水素酸素 $\left(2 \mathrm{H}_{2}+\mathrm{O}_{2}+2 \mathrm{~N}_{2}\right)$ で, 我㓞体と点 火用物体が $1500 \mathrm{~m} / \mathrm{s}(M=4.1)$ の初速度で突入する. 時刻 $30 \mu \mathrm{s}$ には点火用物体の特に端部で圧力が上昇 し, 温度も上昇している。この辺りで爆発的な着火が 起きたと考えられ，時刻 $43 \mu \mathrm{s}$ の等圧力線図は管の上 壁面部に爆風の反射した波形が見られる．この爆発的 着火はデトネーションとなり，時刻 $51 \mu \mathrm{s}$ の等圧力線 図は横波を持ったデトネーション特有の構造を示して いる.デトネーションは高速で伝播し，この計算では 約 $2250 \mathrm{~m} / \mathrm{s}$ て飛翔体の速度よりはるかに速いため， 短時間のうちに追い越してしまい，飛翔体は減速され

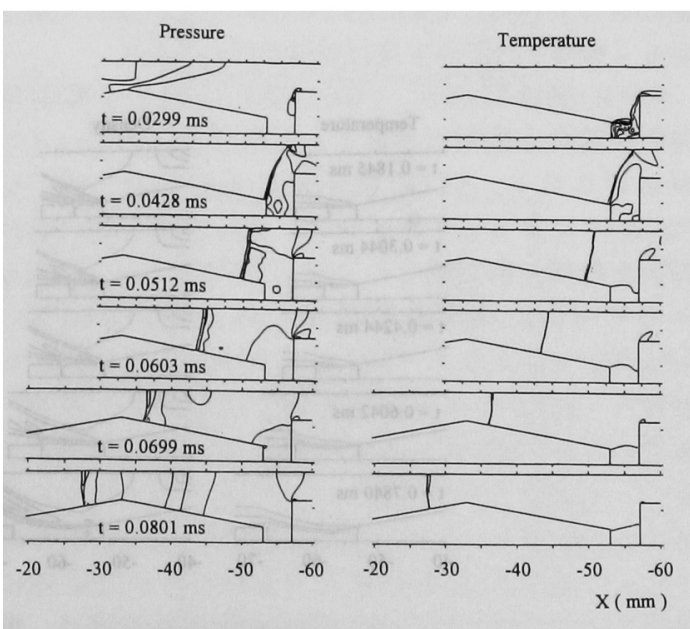

第 4 図 可燃性混合気の場合の計算結果一等温度線図と等 圧力線図の時間変化

ラム加速管内の気体は $2 \mathrm{H}_{2}+\mathrm{O}_{2}+2 \mathrm{~N}_{2}$ て , 初期圧 $0.1013 \mathrm{MPa}$, 初期温度 $293.15 \mathrm{~K}$. 飛㓞体と点火 用物体の初速度は $1500 \mathrm{~m} / \mathrm{s}(M=4.1)$. 
てしまう。

このようにデトネーションが生じてラム加速の状態 に開始できないという問題は実験でも同様である. 文 献 6)に報告した実験結果を第 5 図に引用する。この 実験ではム加速管内に $\mathrm{CH}_{4}+1.4 \mathrm{O}_{2}+1.4 \mathrm{CO}_{2}$ を $0.36 \mathrm{MPa}$ 封入して行ったものであり，数值シミュレ ーションとは湿合気組成・初期圧力が異なっており， また初速度は約 $1000 \mathrm{~m} / \mathrm{s}(M=3.1) て ゙ あ る 。$ 第 5 図 は 3 つの測定点における観測波形で，第 3 図にある圧 カセンサーと磁気センサーの信号のほかに光センサー の信号が LS 1 3 で示される. 飛翔体の通過時刻を

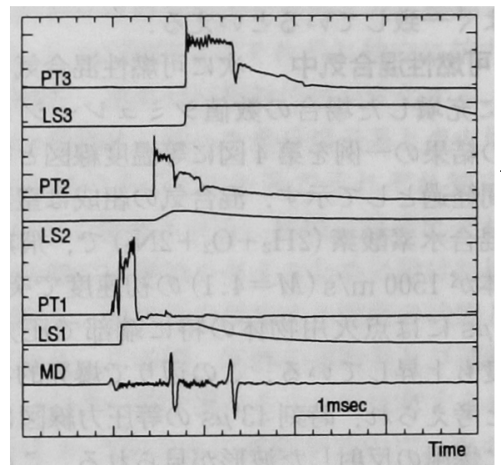

第 5 図 可燃性混合気を用いた実験結果

ラム加速管は王力 $0.36 \mathrm{MPa} の \mathrm{CH}_{4}+1.4 \mathrm{O}_{2}$ $+1.4 \mathrm{CO}_{2}$, 飛蝴体と点火用物体の初速度約 1000 $\mathrm{m} / \mathrm{s} .3$ つの湘定点における圧力センサー $(\mathrm{PT})$ ， 光センサー (LS)，及び碳気センサー（MD）か らの出力. 但し磁気センサーは 3 点の出力を加え 合わせている. 測定点はラム加速管入り口からそ れぞれ $270 \mathrm{~mm}, 1070 \mathrm{~mm}, 1770 \mathrm{~mm}$ である.
示す磁気センサーの信号は 1 つに合わせられ波形 MD で示される．最初の剆定点における圧力波形 PT 1 は 飛㓞体のつくる衝擊波の後方, 少し遅れた点火用物体 の前方に高い圧力の領域がつくられる.ここは燃焼し ていることが光センサー出力 LS 1 からわかる. しか し2 番目の測定点ては, 飛翔体より先に燃焼を伴った 強以圧力波が通過しており，その波の速度約 $2150 \mathrm{~m} /$ sからデトネーションであることが裏づけられる．デ トネーションの発生が数值シミュレーションより遅い のは、混合気がデトネーションを生じにくい組成のた めである．混合気の希釈率をさらに大きくして燃焼速 度を小さくすると着火しなくなってしまう．数值シミ ュレーションにおいても、デトネーションの発生を防 ぐことを検討した．まず第 4 図に示した場合と同じ組 成の混合気で，点火用物体を小さくして高さを $4 \mathrm{~mm}$ として計算したが，着火するとまもなくデトネーショ ンになってしまう。そこで混合気の組成を変え。 $0.5 \mathrm{H}_{2}+\mathrm{O}_{2}+2 \mathrm{~N}_{2}$ として計算した結果が第 6 図であ る.第 6 図には温度, 密度, 圧力及び OH ラジカル の質量分率の等高線の時間経過を示す. $\mathrm{OH}$ ラジカル の分布から一応着火しているものの，管断面全体に败 え広がるようには見えない。したがって燃焼の発热て 熱的にキョーキングすることはできず，圧力もほとん ど上昇しない。飛翔体と管との間に垂直衝撃波がつく られなければ，混合気の流速が大きすぎて圧力を上昇 させるような燃焼状態にはならないと考えられる。こ のように数值シミュレーションにおいても実験におい ても，混合気の組成を変えても，テトネーションにな るか火炎を保持できないか，いずれかになってしま

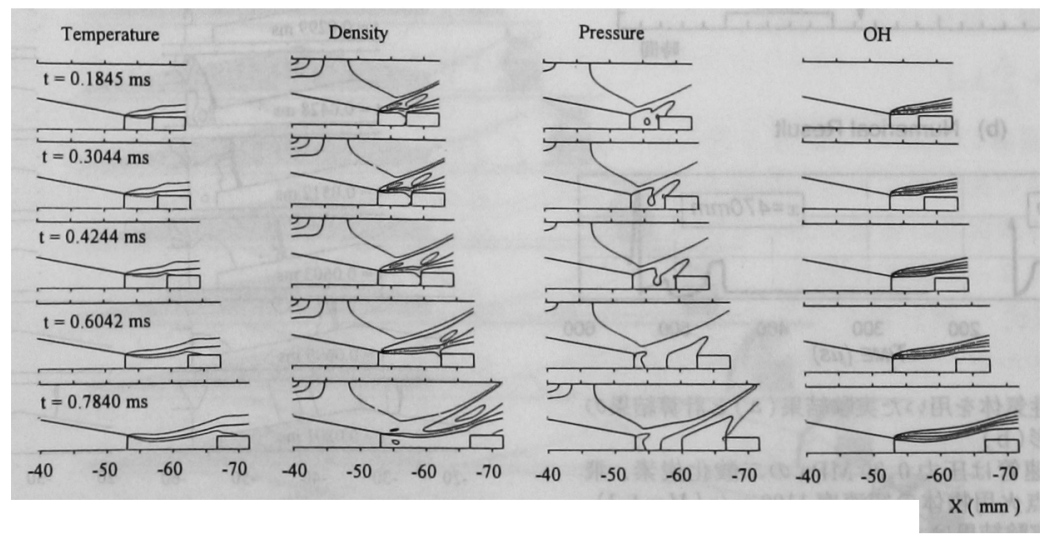

第 6 図 可燃性混合気の場合の計算結果一温度，密度，王力及び OH ラシ カルの筫量分率の等高線の時間変化 ラム加速管内の気体は $0.5 \mathrm{H}_{2}+\mathrm{O}_{2}+2 \mathrm{~N}_{2}$ て、初期圧 $0.1013 \mathrm{MPa}$, 初期温度 $293.15 \mathrm{~K}$. 更錭体と点火用物体の初速度は $1200 \mathrm{~m} / \mathrm{s}(M$ $=3.8$. . 点火用物体の高さは $4 \mathrm{~mm}$. 
い, ラム加速できる状態にスタートさせることが容易 でないことを示した。

C-Jデトネーション速度以下におけるラム加速を実 現するにはさらに何らかの工夫が必要であることを示 したが, 数値シミュレーションの結果は実験結果とよ く対応して扔り，解決法を考える上で数值シミュレー ションが今後重要な役割を果たすことが期待できる.

\section{5. 結論}

（1）二つの独立に高速で運動する物体周りの反応 性流れ場と物体の運動を数值シミュレーションする手 法を確立した。

（2）非燃焼性気体を用いた場合の数值シミュレー ションは実験結果とよく対応しており, 特に点火用物 体がつくりだす重直衝撃波の挙動などが明らかにされ た.

（3）可燃性気体として窒素希釈した水素酸素混合 気を用いて数值シミュレーションした結果，点火用物 体によってつくられる衝撃波で着火すると，容易にデ トネーション発生源となってしまうことを示した。こ のことは実験結果とも一致している．今後持続的なラ 加速が得られるようにする対策を考える上で, 数值 シミュレーションの果たすべき役割が大きいといえ る.

本研究の一部は，文部省科学研究費補助金（基盤研 究 B)「ラム加速装置における燃焼の研究」(課題番号 06452346, 代表 滝 史郎) の援助を得て行われた.

\section{参 考 文 献}

1) Hertzberg, A., Bruckner, A.P. and Bogdanoff, D. W.: Ram Accelerator: A New Chemical Method for Accelerating Projectiles to Ultrahigh Velocities, AIAA J., 26 (1988), pp. 195-203.

2) Giroud, M., Legendre, J.F., Simon, G. and Catoire, L. : Ram Accelerator in $90 \mathrm{~mm}$ Caliber : First Results Concerning the Scale Effect in Thermally Choked Propulsion Mode, 13th International Symposium on Ballistics, 1992.

3) Kruczynski, D., Liberatore, F., Hewitt, J. and Kiwan, M. : Flow Visualization of Steady and Transient Combustion in a 120-mm Ram Accelerator, ARL-TR-1059, April 1996.

4) Nusca, M. J.: Reacting Flow Simulations for a Large Scale Ram Accelerator, 30th AIAA/ASME/SAE/ASEE Joint Propulsion Conference, AIAA 94-2963, June 1994.

5) Chang, X., Kanemoto, H. and Taki, S. : A Ram Accelerator with Rectangular Bore Is Working at Hiroshima University, 31st AIAA/ASME/SAE/ASEE Joint Propulsion Conference and Exibit, San Diego, CA, AIAA Paper, 95-2496, 1995.

6) 張 新宇, 下村幸治, 滝 史郎：二次元ラム加速器の開発及 びディフューザーの性能試験，日本航空宇宙学会誌，44 (1996), pp. 568-575.

7) Zhang, C., Inoue, H. and Taki, S. : Direct Numerical Simulation of Flow Field with Combustion in Ram Accelerator, 20th ISTS, Paper 96-a2-17, 1996.

8）倉谷健治：燃焼に伴う環境污染物質の生成機構と抑制法，日 本機械学会編, 日本機械学会, 東京, 1980, p. 3.

9) Taki, S. : Numerical Simulation of Standing Detonation Induced by Oblique Shock Wave, Proc. of the International Symposium on Computational Fluid Dynamics, Nagoya, Japan Society of Computational Fluid Dynamics, Vol. I, 1989, pp. 113-118.

10) Lomax, H. and Baily, H. E. : Linearized Implicit Scheme, NASA TN D-4109, 1967.

11) van Leer, B.: Schemes Stabilized by Diffusion, J. Computational Physics, 3 (1969), pp. 473-485. 